\title{
The effects of blockchain technology adoption on business ethics and social sustainability: evidence from the Middle
} East

\author{
Mohammad Hossein Ronaghi $^{1}$ (D) Mohammad Mosakhani ${ }^{2}$
}

Received: 4 March 2021 / Accepted: 12 July 2021 / Published online: 9 August 2021

(c) The Author(s), under exclusive licence to Springer Nature B.V. 2021

\begin{abstract}
Sustainable development is not just possible with regard to the environmental and economic dimensions, and social issues are also important in achieving sustainable development. Social sustainability, as one of the dimensions of sustainable development, has been considered by policy makers and managers. Social sustainability and business ethics in the organization are affected by social and behavioral interactions of individuals. Blockchain technology, as a disruptive technology, leads to a peer-to-peer and decentralized network management using distributed architecture. Blockchain technology can affect the way information is exchanged and creates transparency in the organization. Therefore, the purpose of this study is to evaluate the impact of blockchain technology on business ethics and social sustainability in the organization. In the first part of the research, a conceptual model is extracted using previous studies. In the second part, the relationship between model variables among 411 managers of small and medium enterprises (SMEs) active in the Middle East region is evaluated according to the importance of sustainability in this region. Structural equation model and SmartPLS software have been used for data analysis. The research findings show that the use of blockchain technology has a direct impact on business ethics, corporate governance and social sustainability due to the creation of a decentralized system, information transparency and traceability. Also, business ethics and corporate governance have an impact on achieving social sustainability.
\end{abstract}

Keywords Blockchain · Business ethics $\cdot$ Social sustainability $\cdot$ Corporate governance

Mohammad Hossein Ronaghi

mh_ronaghi@shirazu.ac.ir

Mohammad Mosakhani

mosakhani@ut.ac.ir

1 Department of Management, School of Economics, Management and Social Sciences, Shiraz University, Shiraz, Iran

2 Department of Information TechnologyManagement, University of Tehran, Tehran, Iran 


\section{Introduction}

Sustainable development, as one of the major challenges worldwide, has attracted the attention of many researchers and policy makers (Liu et al., 2011). Today, sustainable development plays an essential role in business survival by increasing regulatory pressures imposed by stakeholders and existing production practices (Hahn \& Figge, 2018). The concept of sustainability refers to responsible behavior regarding the environment, society and future generations (Clark, 2007). Corporate sustainability can be considered as meeting the needs of direct and indirect stakeholders of the company, including shareholders, employees, customers, regulatory bodies, and part of the body of society so that the needs of future stakeholders are not endangered (Mani et al., 2016). One of the first studies in the field of sustainability was Harding's (1968) research, in which the concept of sustainability was related to the concepts of environment and resource depletion. Subsequent studies used the triple-bottom-line approach to sustainability and introduced sustainability with three environmental, economic, and social dimensions (Carter \& Easton, 2011).

Today, companies have realized that their economic development requires simultaneous attention to social issues and environmental protection (Lu et al., 2020). Tang (2018) believes that the issue of social sustainability in emerging economics has not yet been fully addressed by researchers and needs further investigation. Social sustainability is also called corporate social responsibility (CSR) and is a responsible and voluntary action in which social concerns are integrated with organizational operations and shareholder interactions (Rai et al., 2021). Hence, social sustainability refers to the management of social issues along the value chain and at the same time ensures the long-term survival of the organization (Mani et al., 2016). These social aspects include not only the internal dimensions of the organization, but also how to interact with other organizations, external stakeholders, and the body of the society (Carter \& Rogers, 2008). Rai et al. (2021) showed social sustainability is a major concern during the COVID-19 pandemic. Various studies have pointed to the role of social sustainability and the performance of organizations and businesses. In this regard, Mani et al. (2020) showed that there is a positive relationship between social sustainability activities and supply chain performance among 327 samples of small businesses. Haq and Boz (2019) evaluated the environmental, social and economic sustainability in the field of agriculture in Turkey. Lee et al. (2019) assessed social sustainability in terms of organizational output, customer output, and employee output among 400 small businesses. Business ethics, as behavioral characteristics of people in the workplace, is the basis of social interactions of individuals; therefore, it is of utmost importance as one of the factors affecting social aspects in an organization. In this regard, Lashley (2016) examined the relationship between business ethics in sustainable hospitality. Krishna et al. (2011) examined the sustainability approach in business ethics and corporate performance. Corporate governance plays an important role in shaping social behaviors in the organization due to the way stakeholders monitor the behavior of executive agents and power structure (Aguilera et al., 2009). Krechovská and Prochazkova (2014) studied the relationship between the concept of sustainability and corporate governance with respect to corporate performance management. Digital transformation has been effective on business models, presentation of services, goods production and governance procedures in organizations (Castelo-Branco et al., 2019).

The improvement of information technology infrastructure, and the improvement of the ability to analyze environmental data lead an organization or a business to achieve a competitive advantage (Grover \& Kohli, 2013). Although the dimensions of digital transformation are numerous, those components that have impact on businesses and different industries, and have 
been considered by researchers and managers of organizations, are recognized as industry 4.0, presented in 2011 (Hofmann \& Rüsch, 2017). Ronaghi and Forouharfar (2020) believe "The concept of 'Industry 4.0' is directly related to the installation of smart equipment and instruments for optimal controlling of resources, as well as increasing efficiency besides improving flexibility" (Ronaghi \& Forouharfar, 2020, p.2). The presence of time stamps in the blockchain structure prevents any distortion and falsification of information without the knowledge of stakeholders. Therefore, this collective responsibility increases the security and reliability of data (Raval, 2016). Using distributed, open-source, peer-to-peer systems, blockchain has the potential to create cleaner economic processes and harmony and balance between the economy, society and the environment (Upadhyay et al., 2021). On the other hand, due to the distribution of information in the blockchain network, the method of interaction between users, energy consumption and waste of resources are among the challenges of using this technology (Upadhyay et al., 2020). Given the features and challenges, this technology can affect sustainable development (Schulz et al., 2020).

Given the important role of digital transformation in organizations as well as the importance of sustainability, the present research problem is to provide a model to identify the relationship between blockchain technology adoption and social sustainability, business ethics, and corporate governance. The issue of sustainability and how to use natural resources is very important in the Middle East given that most of the region's economies are dependent on oil and also face a water crisis. Also, because SMEs have less financial and human resources than large businesses, achieving sustainability poses many challenges for them. Therefore, identifying the factors affecting sustainability can facilitate the path to achieve sustainability. Accordingly, the model presented in this study was evaluated among SMEs in the Middle East. Previous studies have not examined the relationship between blockchain technology and social sustainability. In addition, model evaluation in the Middle East is a research innovation. According to the main research objective regarding the impact of blockchain technology adoption on social sustainability and corporate governance mechanism, the research questions are:

- What effect does blockchain adoption as a disruptive technology have on social sustainability?

- How is blockchain adoption related to corporate governance?

- How is blockchain adoption related to business ethics?

The results of this study theoretically contribute to the provision of a model for identifying the impact of blockchain technology, business ethics and corporate governance on social sustainability in the development of sustainability knowledge. From a managerial point of view, the findings of this study provide insights for business managers and policymakers in the Middle East to identify the importance of using blockchain technology and its impact on achieving sustainability and improving corporate governance.

\section{Literature Review}

\subsection{Blockchain and Ethics}

Blockchain technology was introduced as the new generation Internet. Blockchain as a disruptive technology is able to change financial transactions, affect the interactions of individuals and even society (Zachariadis et al., 2019). Narayanan and Clark (2017) believe that there is no exact definition for blockchain, it is rather an umbrella concept of various 
components introduced as a platform for bitcoin based on a distributed system. Due to the pervasiveness of blockchain software applications, this technology has significant effects on businesses and society (Davidson et al., 2018). Blockchain technology, due to its special features, can affect the way people interact in the organization. One of the features of blockchain technology is immutability, which reduces or eliminates the power of managers to control business transactions (Ronaghi, 2020). Accordingly, any fraud and personal use through information theft or distortion is restricted (Brav \& Mathews, 2011). Blockchain technology brings transparency to business processes and ethical codes, such as honesty, consideration, and responsibility, which lead to accurate tracking of executive services and valuation of organizational assets (Tapscott \& Tapscott, 2017).

Due to the distributable information system in the blockchain network, this technology can be effective on organizational competition (Catalini \& Tucker, 2018). Ability to access information and create transparency for all users, makes the operation of this technology in line with human and citizenship rights (Hughes, 2017). The distributable blockchain system builds a strong technocratic power structure, and the use of hash and encryption functions promotes social trust and network-level coordination (Filippi \& Loveluck, 2016). Blockchain can address ethical challenges in data-driven science by creating a secure network (Rahimzadeh, 2018).

It is very important to follow the rules and regulations in blockchain communities (Herian, 2018). Numerous studies have been conducted on the relationship between blockchain and ethical issues. Fischer (2018) believes that the use of blockchain can be effective in addressing ethical challenges in finance and accounting. Tang et al. (2020) provided a framework regarding the ethical principles of blockchain based on Understanding, Technology, Application and Regulation (UTAR). Accordingly, stakeholders must first be aware of the ethical challenges and benefits of blockchain technology. Second, blockchain as an emerging technology must consider ethical values. Then, blockchain-based applications must respect ethical values, and ultimately, the use of blockchain applications must be subject to ethical rules. According to the previous studies, it is also assumed that blockchain can be effective on ethical behaviors and human interactions in the organization and business. According to the theoretical issues of the relationship between blockchain and ethical issues, the first research hypothesis is formed:

$\mathbf{H}_{1}$ Blockchain Adoption has positive impact on Business Ethics.

\subsection{Blockchain and corporate governance}

Corporate governance is the system by which organizations are directed and controlled. Corporate governance plays an important role in company performance. Poor corporate governance can jeopardize the interests of stakeholders and lead to business losses ( $\mathrm{Li}$ et al., 2020). Corporate governance is a mechanism that considers managerial accountability, board structure and shareholder rights in multi-member organizations (Cheffin, 2013). Elgammal et al. (2018) showed four dimensions related to the success of the corporate governance: transparency of financial data, ownership structure, structure of the board of directors and auditing committee. Internal and external mechanisms of corporate governance seek to reduce organizational costs and ensure an effective decision-making process with the aim of increasing organizational wealth (Ahlering \& Deakin, 2007). Good corporate governance has several benefits for the organization, including lower capital costs, better organizational performance, easier 
access to external resources, and appropriate behavior in line with the interests of shareholders (Claessens \& Yurtoglu, 2013). Blockchain technology enhances the regulatory aspect of processes by controlling transactions by nodes. De Filippi et al. (2020) examined the issue of trust and confidence in the blockchain system. Confidence in blockchain system depends on the governance structure. Governance in a blockchain system requires trust in distributed network operators (De Filippi et al., 2020).

Various theories have been proposed regarding corporate governance. One of these theories developed by Williamson (1996) is transaction cost theory. Transaction cost theory is a multidisciplinary field of law, economics and organizations. In this theory, the organization consists of people who have different goals and perspectives and the organizations have grown to the point where they replace the market. Based on this, the product and its price are determined by the organization and its structure. In another theory, which has an economic and material perspective and is known as agency theory, managers are introduced as people who pursue their personal interests and prefer individual interests to the interests of the organization. In this view, solutions should be found that guide the goals of managers and the organization in one direction and transform the manager from the mode of agent of the organization to the servant of the organization (ElGammal et al., 2018). Another theory is called resource dependency theory. This theory focuses on the role of managers in providing the resources needed by the organization. Hillman et al. (2000) argue that in this theory, managers' relationship with the external environment is crucial in sourcing. For example, managers bring resources to the corporate such as information, skills, access to suppliers, customers and social groups.

Today, there is a consensus that blockchain has changed the financial, regulatory, and corporate governance processes (Akgiray, 2019). Blockchain capabilities lead to digital product tracking, authentication, digital rights management, fraud prevention, and the creation of autonomous organizations (Goel, 2015). It can be argued that blockchain technology creates value for traditional organizations and leads them toward the firm-society interface and/or fluid digital networks with a governance structure similar to informal barter (Risius \& Spohrer, 2017). Blockchain technology can be introduced as an open-source distributed system in which transactions between different stakeholders can be simultaneously recorded and updated. It also facilitates transactions in a permanent and verifiable manner (Iansiti \& Lakhani, 2017). Yermack (2017) stated that blockchain technology is consistent with corporate governance and results in greater liquidity, lower costs, accurate record keeping, and transparent ownership. Clearly, corporate governance goals can be a useful guide to re-understanding financial regulations and revising public policies to comply with blockchain technology (Akgiray, 2019). Kaal (2021) believes that the governance structure of decentralized autonomous organizations will not have the problems of today and the information at the edges of the system can be monitored and controlled. Therefore, the effect of blockchain on the corporate governance structure can be understood. Considering the relationship between blockchain capabilities and corporate governance, the second research hypothesis is formulated:

$\mathrm{H}_{2}$ Blockchain Adoption has positive impact on Corporate Governance.

\subsection{Social sustainability}

Sustainability can be considered as a strategic resource that leads to a competitive advantage for the organization and results in better organizational performance. Today, 
organizations seek to gain a competitive advantage through the integration of sustainability into their business strategies (Hult, 2011). Sustainability is created by combining three economic, ecological, and social components (Bansal, 2005). However, much of the business effort is focused on economic and ecological issues. But the influence of individuals in the formation of sustainability and the concept of social sustainability should not be overlooked (Ajmal et al., 2017). Given the importance of human resources in the organization and the position of consumers in a business, the social dimension of sustainability plays an important role (Pfeffer, 2010). Social sustainability is the ability of organizations to increase value through the promotion of human capital and social capital in the communities they work with (Lee et al., 2019). The results of some studies showed that social sustainability has a positive and significant relationship with organizational strategy (Darcy et a., 2014; Paille et al., 2018). Dimensions of social sustainability in the organization include work condition, work environment, work safety, and skill development (Digalwar et al., 2019).

Mani et al. (2016) examined the social sustainability of the supply chain in developing countries. They identified society, health and safety, ethics, equity, labor rights, philanthropy, child and bonded labor, wages, education, and housing as dimensions of social sustainability of supply chain. Gelhard and von Delft (2016) believed that paying attention to consumers, as external stakeholders of a business, affects the social sustainability of the organization. Attention to consumers is influenced by accurate knowledge of the market, accurate analysis of consumer needs, and capabilities of the product or service provider. Consumers need to track and access product information in order to achieve sustainability (Nikolakis et al., 2018). Blockchain technology makes it possible to track product information and enterprise transactions at the network level. Kewell et al. (2017) introduced the concept of "blockchain for good" and believed that blockchain has an impact on the sustainable development of an organization. Blockchain capabilities to promote sustainability include four items of: (1) designing incentive mechanisms to promote green consumer behavior, (2) increased monitoring and follow-up throughout the product life cycle, (3) increased system productivity by reducing development and operating costs, and (4) strengthened sustainability monitoring and performance reporting through supply chain networks (Esmaeilian et al., 2020).

Venkatesh et al. (2020) argued that blockchain is a guaranteed future for traceability in supply chain social sustainability. In their study, they presented a blockchain-based system architecture, the Internet of Things, and big data that enable vendors to monitor supply chain social sustainability. A database in supply chain can be considered to monitor supplier sustainability (Asif et al., 2019), and blockchain can facilitate and ensure such monitoring. In their study, Kouhizadeh et al. (2020) presented an environmental-organizational-technological framework and examined the barriers to blockchain adoption to achieve sustainability. Blockchain helps with social responsibility by preventing fraudulent transactions. It also shifts new financial models to more sustainable investments that help the economy (Schulte, 2013). Also, Leng et al. (2020) pointed out how the blockchain overcomes the barriers to sustainability and examined the two perspectives of the product life cycle and the manufacturing system. Kumar et al. (2019) showed that lack of information sharing, lack of customer awareness and lack of voice are factors affecting the implementation of a sustainable supply chain. Therefore, the use of blockchain technology can help share information and create transparency at the network level using a distributed system. Considering the relationship between the blockchain and sustainability, as well as the social impact of blockchain, the third hypothesis is formulated as follows: 
$\mathbf{H}_{3}$ Blockchain Adoption has positive impact on Social Sustainability.

Business ethics provides an analytical framework for evaluating managerial performance, in general, and sustainability behavior, in particular (Lashley, 2016). The results of the study by Elgammal et al. (2018) pointed to the positive impact of ethics on social responsibility among small businesses in the MENA region. Ferrell et al. (2019) examined customer brand research in the field of business ethics and social responsibility and evaluated four scenarios in this regard. Lashley (2016) considered business ethics to be related to the concept of sustainability and referred to the concept of ethical sustainability. Ethical sustainability is related to social development and is defined beyond pious statements as a strategic commitment that is actively monitored in the organization (Lashley, 2016). Barau et al. (2016) emphasized the importance of environmental ethics as a means of engaging society, businesses and policymakers to achieve sustainability. Stahl et al. (2019) examined the information and communication technology industry and showed that a transparent mechanism for ethical behaviors in the organization is effective to achieve sustainability. Considering the regulatory framework in corporate governance and the interests of stakeholders mentioned in previous studies, this study also assumes that there is a relationship between corporate governance and organizational ethics, and the fourth hypothesis is formulated:

$\mathbf{H}_{4}$ Business Ethics has positive impact on Social Sustainability.

The concept of corporate sustainability is the ability of companies to positively influence environmental, social and economic development through governance practices and market presence (Krechovská \& Prochazkova, 2014). The results of the study by Elgammal et al. (2018) showed the positive impact of corporate governance on social responsibility among small businesses in the MENA region. Schrobback and Meath (2020) argued that a comprehensive approach is needed to evaluate corporate sustainability strategies, and provided a framework in which the role of sustainability strategy in corporate's sustainability governance is demonstrated. The composition of the board has an effect on the sustainability performance of the organization. Also, board diversity and differentiation of the head of the board from the CEO has a positive role in the environmental performance of the organization (Naciti, 2019). Krechovská and Prochazkova (2014) examined the requirements of corporate governance and its impact on society with respect to the concept of sustainability. The results of their study revealed that although the concept of sustainability is not included in the business processes of SMEs, organizations are aware of the importance of the concept of sustainability in their organizational performance in the long run. Salvioni and Gennari (2014) argue that given the importance of corporate sustainability, the use of corporate governance mechanisms allows stakeholders to better monitor the performance of executives in terms of resource spending, social responsibility and attention to the environment. According to the theoretical background regarding the relationship between corporate governance and the concept of sustainability, the fifth hypothesis is formed:

$\mathbf{H}_{5}$ Corporate Governance has positive impact on Social Sustainability. Based on the research hypotheses and the relationships between research constructs, a conceptual model is developed as Fig. 1 


\section{Methodology}

The present study is applied that was conducted in spring and summer 2020. According to the research onion presented by Saunders et al. (2012), the research method was survey. The research approach was deductive and the research strategy is positivism. A positivist researcher begins his study based on existing theories and seeks to test and develop the theory. The positivist researcher does not influence the research findings and acts in a neutral way (Saunders et al., 2012, p. 137). According to the study population, positivism strategy was used to research and test the existing hypotheses in the population. The required data were collected using a questionnaire. The designed questionnaire consisted of five parts ("Appendix"). The first part included a cover letter to explain the constructs and the purpose of the research to the participants along with four demographic questions. The second part was related to the blockchain adoption questions taken from the recent study by Orji et al. (2020) that included technological factors (7 questions), organizational factors (6 questions), and institutional factors (5 questions). The third part was related to corporate governance questions in accordance with ElGammal et al. (2018) research criteria that included transparency (9 questions), audit committee ( 9 questions), board of directors (19 questions), and ownership structure ( 9 questions). The fourth section was related to 13 business ethics questions according to ElGammal et al. (2018). The reason for choosing the ElGammal et al. (2018) study questionnaire was the statistical population of MENA region, which is similar to the study area of this study. Finally, the fifth part was related to the social sustainability questions according to the Digalwar et al. (2019) study that included work condition (5 questions), work environment (4 questions), work safety (3 questions), and skill development (2 questions). Digalwar et al. (2019) study is one of the few studies that have accurately extracted social sustainability indices at the organizational level. The questionnaire was designed and revised according to the opinion of seven experts in the field of management and the faculty members. Therefore, it can be claimed that the questionnaire has acceptable (face) validity. Convergent reliability is acceptable when composite reliability (CR) is equal to or greater than 0.7 and average variance extracted (AVE) is equal to or greater than 0.5 (Fornell \& Lacker, 1981). The values of these indices are shown in Table 1. Cronbach's alpha coefficient and Dillon-Goldstein (DG) rho were used to evaluate the reliability of the research instrument. The value of these coefficients is also shown in Table 2. Given that the index is larger than 0.7 , it can be claimed that the questionnaire has an acceptable reliability (Esposito Vinzi et al., 2010).

Another validity measurement, discriminant validity examines the extent to which a latent variable is truly distinct from other latent variables in predicting the dependent

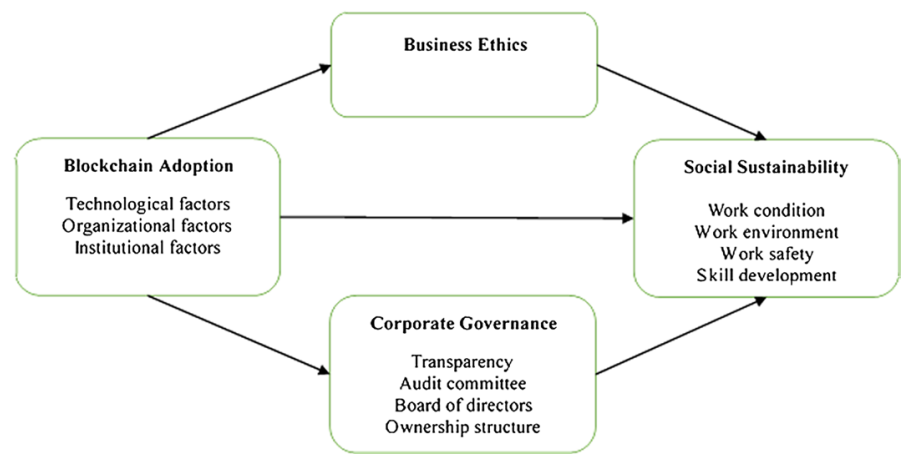

Fig. 1 The proposed conceptual framework 
variable (Hair et al., 2016). One popular approach to assess discriminant validity, which was also implemented in the current research, was through examining the correlation matrix among constructs. The results which are presented in Table 2 indicate the acceptability of the research discriminant validity.

The countries of the Middle East are mainly developing countries based on oil economies. More than $64.5 \%$ of OPEC oil is produced in the Middle East. Saudi Arabia (267.03 billion barrels), Iran (155.60 billion barrels), Iraq (145.02 billion barrels), Kuwait (101.50 billion barrels) and the United Arab Emirates (97.80 billion barrels) are among the largest oil exporters in the world (OPEC, 2019). Therefore, natural resources play an important role in the economic system of the Middle East countries. Due to the water crisis, semiarid regions of Asia, such as the Middle East and sub-Saharan Africa, are more likely to face this problem. As one of the countries in the Middle East, Iran is expected to face a serious drought crisis in the next 30 years (Yazdanpanah et al., 2015). Izraeli (1997) conducted a study on the business ethics of the people of the Middle East and pointed to their interest in environmental issues. Therefore, paying attention to the issue of sustainability and how to consume natural resources with respect to future generations is of particular importance in this region. Accordingly, it is important to study the factors affecting social sustainability in this region. On the other hand, countries in the region have unique socioeconomic characteristics, such as common religious values, social conflicts and the role of the state, which affect the similarities of social behavior and individual morality (Mertzanis et al., 2018). In this regard, three countries of Iran, Iraq, and Turkey were selected. These three countries, like most countries in the Middle East, are developing countries. On the other hand, given that these three countries have Persian, Arab and Turkish races, so morally and culturally can be a credible example for countries in the region. Accordingly, the statistical population of this study included managers and CEOs of all SMEs active in these three countries. Using a convenience sampling method, 530 electronic questionnaires were sent to CEOs and managers of SMEs and 411 completed questionnaires were received. Path analysis and SmartPLS software were used to test the research hypotheses due to the software's ability to analyze causal relationships among several variables.

\section{Results}

The demographic information of the participants in Table 3 indicates that most of them had more than 15 years of work experience, meaning that participants had an acceptable level of expertise. Also, $74 \%$ of the companies were medium.

Table 4 shows the mean values and standard deviation of the research variables. The minimum value was 1 , and the maximum value was 5 for the items used in this research. The mean value of the items ranged from 2.461 to 4.311 , and the standard deviation ranged from 0.322 to 0.941 .

According to the obtained $P$-Value $(<0.05)$ and t-statistic values in Table 5, all research hypotheses were accepted at $95 \%$ confidence level. Based on the results of the hypotheses' testing, it is clear that blockchain technology has a positive effect on business ethics, corporate governance and social sustainability. Also, business ethics and corporate governance have a positive effect on social sustainability.

Figure 2 shows the final model of the study along with the path coefficients. Model coefficients show that the degree of blockchain adoption has a direct impact on business ethics, 


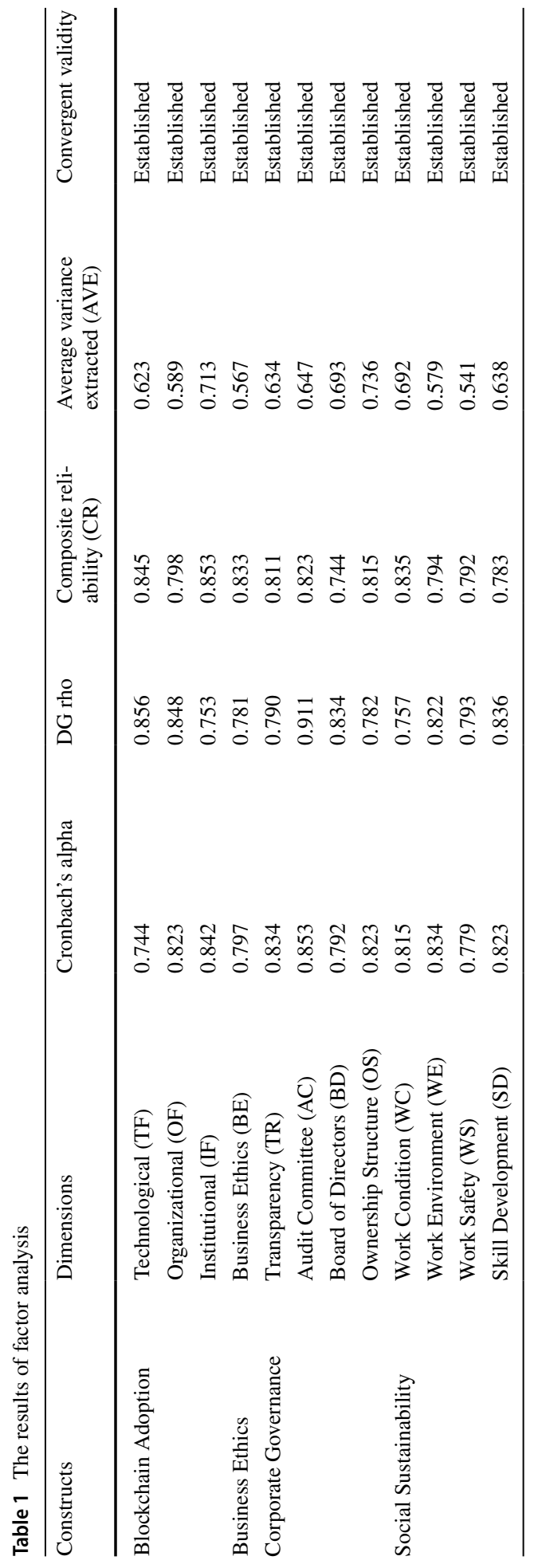


Table 2 Discriminant validity and correlation

\begin{tabular}{lllllllllllll}
\hline & TF & OF & IF & BE & TR & AC & BD & OS & WC & WE & WS & SD \\
\hline TF & $\mathbf{0 . 8 7 7}$ & & & & & & & & & & & \\
OF & 0.583 & $\mathbf{0 . 7 5 9}$ & & & & & & & & & & \\
IF & 0.287 & 0.608 & $\mathbf{0 . 8 4 4}$ & & & & & & & & & \\
BE & 0.397 & 0.503 & 0.639 & $\mathbf{0 . 9 2 7}$ & & & & & & & & \\
TR & 0.408 & 0.478 & 0.450 & 0.576 & $\mathbf{0 . 7 9 8}$ & & & & & & & \\
AC & 0.344 & 0.559 & 0.503 & 0.419 & 0.559 & $\mathbf{0 . 8 5 7}$ & & & & & & \\
BD & 0.319 & 0.234 & 0.234 & 0.287 & 0.234 & 0.378 & $\mathbf{0 . 9 1 1}$ & & & & & \\
OS & 0.423 & 0.513 & 0.489 & 0.324 & 0.513 & 0.526 & 0.256 & $\mathbf{0 . 8 4 2}$ & & & & \\
WC & 0.335 & 0.178 & 0.356 & 0.349 & 0.583 & 0.619 & 0.354 & 0.253 & $\mathbf{0 . 7 8 5}$ & & & \\
WE & 0.213 & 0.265 & 0.413 & 0.429 & 0.439 & 0.287 & 0.316 & 0.381 & 0.266 & $\mathbf{0 . 8 5 2}$ & & \\
WS & 0.267 & 0.342 & 0.289 & 0.452 & 0.559 & 0.234 & 0.267 & 0.385 & 0.327 & 0.335 & $\mathbf{0 . 8 6 8}$ & \\
SD & 0.372 & 0.316 & 0.416 & 0.311 & 0.352 & 0.265 & 0.189 & 0.324 & 0.413 & 0.292 & 0.258 & $\mathbf{0 . 9 2 3}$ \\
\hline & & & & & & & & & & & & \\
\hline
\end{tabular}

Table 3 Demographic information $(\mathrm{N}=411)$

\begin{tabular}{llll}
\hline Demographic character & & Frequency (n) & Percentile (\%) \\
\hline \multirow{4}{*}{ Country } & Islamic Republic of Iran & 179 & 44 \\
& Iraq & 108 & 26 \\
Company size & Turkey & 124 & 30 \\
& Small enterprise & 109 & 26 \\
Respondent's years of experience & Medium enterprise & 302 & 74 \\
& $<10$ & 111 & 27 \\
& $10-15$ & 59 & 14 \\
Size of board of directors & $15-20$ & 168 & 41 \\
& $>20$ & 73 & 18 \\
& $1-4$ & 156 & 38 \\
& $5-10$ & 255 & 62 \\
\hline
\end{tabular}

Table 4 Descriptive statistics

\begin{tabular}{llll}
\hline Variable & $\mathrm{N}$ & Mean & Std. deviation \\
\hline Technological (TF) & 411 & 4.311 & 0.456 \\
Organizational (OF) & 411 & 2.848 & 0.858 \\
Institutional (IF) & 411 & 4.012 & 0.753 \\
Business Ethics (BE) & 411 & 2.717 & 0.681 \\
Transparency (TR) & 411 & 2.836 & 0.540 \\
Audit Committee (AC) & 411 & 2.853 & 0.941 \\
Board of Directors (BD) & 411 & 3.726 & 0.334 \\
Ownership Structure (OS) & 411 & 2.973 & 0.412 \\
Work Condition (WC) & 411 & 2.715 & 0.657 \\
Work Environment (WE) & 411 & 3.634 & 0.322 \\
Work Safety (WS) & 411 & 2.461 & 0.725 \\
Skill Development (SD) & 411 & 3.713 & 0.890 \\
\hline
\end{tabular}


Table 5 Structural model assessment

\begin{tabular}{lllcll}
\hline Hypothesis & $\begin{array}{l}\text { Original Sample } \\
(\beta)(>0.1)\end{array}$ & Std. err & t-statistics $(>1.96)$ & $P$-Value $(<0.05)$ & Result \\
\hline $\mathrm{BA} \rightarrow \mathrm{BE}\left(\mathrm{H}_{1}\right)$ & 0.343 & 0.034 & 4.371 & 0.007 & Supported \\
$\mathrm{BA} \rightarrow \mathrm{CG}\left(\mathrm{H}_{2}\right)$ & 0.411 & 0.048 & 7.943 & 0.012 & Supported \\
$\mathrm{BA} \rightarrow \mathrm{SS}\left(\mathrm{H}_{3}\right)$ & 0.567 & 0.052 & 3.964 & 0.002 & Supported \\
$\mathrm{BE} \rightarrow \mathrm{SS}\left(\mathrm{H}_{4}\right)$ & 0.229 & 0.041 & 11.284 & 0.005 & Supported \\
$\mathrm{CG} \rightarrow \mathrm{SS}\left(\mathrm{H}_{5}\right)$ & 0.296 & 0.037 & 3.775 & 0.001 & Supported \\
\hline
\end{tabular}

Fig. 2 Hypotheses testing

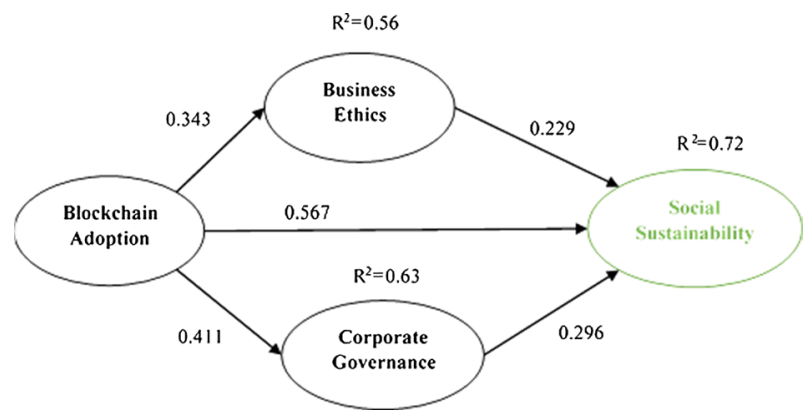

corporate governance and social sustainability, and among these, the blockchain adoption has had the greatest impact on social sustainability. Also, the variables of business ethics and corporate governance have affected the social sustainability of SMEs. Moreover, $\mathrm{R}^{2}$ coefficients show that the model was able to explain $56 \%$ of the variance in business ethics and $63 \%$ of variance in corporate governance and $72 \%$ of variance in social sustainability.

\section{Discussion}

Since the beginning of the twenty-first century, the vision of sustainable development has not just focused on the environmental or economic dimensions, but social issues have created a new perspective on achieving sustainable development. Today, due to the economic problems facing organizations, attention to financial interests is opposed to social interests and may affect their investment in social behaviors (Sajko et al., 2020). Therefore, it is important to address social sustainability and the factors affecting it. Social sustainability has received special attention from policymakers and managers as an essential component of sustainable development. In this study, the effect of the three variables of blockchain adoption, business ethics and corporate governance on social sustainability among SMEs in the Middle East was confirmed in the form of a model. In this study, it was assumed that acceptance of blockchain can affect the communication mechanism between individuals and their social and moral behaviors. The impact of business ethics and corporate governance on social sustainability was also confirmed. According to the research objective, identifying the relationship between business ethics, corporate governance and blockchain with social sustainability shows the factors related to promoting sustainable behavior in the companies under study. In some studies (e.g., Gupta \& Sadoghi, 2018; Hang \& Kim, 2021), the technical dimension of blockchain has just been addressed, or in some studies (e.g., Hu 
et al., 2021), the blockchain has been considered only as a platform for digital currency and bitcoin. However, in this study, it was shown that the use of this technology is not only the financial and cryptic dimensions, and the impact of this technology on the ethical and social dimensions in the organization was also shown. Therefore, organizations should also pay attention to its social effects in using blockchain. Some studies, such as Schuetz and Venkatesh (2019) (financial industry) and Orji et al. (2020) (fright logistics industry), have examined blockchain in a specific industry, but SMEs were examined in this study. One of the challenges of blockchain technology use is energy consumption and waste of resources. Since blockchain was initially introduced as a platform for bitcoin cryptocurrencies, Siegfried et al. (2020) showed that bitcoin consumes the same amount of energy as electricity consumed in Ireland. Also, in Frizzo-Barker et al. (2020) study, the negative effects of blockchain on environmental dimensions and energy consumption were pointed out, but the present study points out to the positive effect of this technology on the social dimension of sustainability. It should be noted that blockchain at the level of an organization can be set up privately and with limited nodes, and the amount of energy consumption in such a network is not comparable to the public bitcoin network. As a result, the use of this technology is complex and has positive effects and different challenges for the organization.

\subsection{Theoretical contributions}

Theoretically, the result of the first hypothesis of the research showed the positive effect of blockchain technology adoption on business ethics. Accordingly, blockchain can provide a platform for equal access and sharing of information in the organization using distributed ledger (Helo \& Hao, 2019). On the other hand, cryptographic capabilities and hash functions improve information security, prevent information distortion, and reduce information fraud and corruption behaviors (Bahga \& Madisetti, 2016). Electronic voting is one of the capabilities of the blockchain technology (Piazza, 2017) and can prevent some immoral behaviors related to elections. Arab workers in the Middle East embrace moral relativism. Although they are no less moral than other people in the world, they adopt unethical behaviors in the workplace (Al-Khatib et al., 2002). Given the role of business ethics, it can be acknowledged that blockchain technology underlies ethical codes such as justice, democracy and trust in the organization. Based on the results of the second hypothesis of the research, it was found that the use of blockchain technology in the organization has a positive effect on corporate governance. This finding, based on the transparency of information generated by blockchain, leads to better oversight of the board of directors and stakeholders on the performance of executive agents in the organization. The use of multiple ledgers through blockchain technology facilitates processes and reduces costs in the organization (Catalini \& Gans, 2016). Blockchain is based on distributed consensus instead of trusted third party (Peng et al., 2020), i.e., decentralization of information moderates' power at different levels of the organization and prevents corruption. The use of smart contracts, as one of the capabilities of blockchain technology, facilitates the organization's relations with partners, employers, and customers (Saberi et al., 2018). In this regard, stakeholders can better monitor the organization's external interactions. Utilizing digital currencies under the blockchain platform enables more corporate financial controls and transparent financial statements (Farouk et al., 2020). This feature is effective in financially monitoring the executive agents of the organization. Lafarre and Van der Elst (2018) believe that blockchain has a positive effect on corporate governance due to real-time accounting ownership, efficient shareholders meetings, greater transparency of ownership. According to 
theories of corporate governance, it can be said that one of the challenges mentioned in agency theory is the profit-seeking behavior of executives that blockchain can control and inform users' decisions by creating transparency in the network and cause better monitoring of managers' performance. Although distributed ledgers are known as decentralized systems because many network nodes use a database, they are logically centralized because there is a single shared ledger (Zachariadis et al., 2019). Therefore, according to agency theory, blockchain technology creates a better monitoring system on the performance of network nodes. In line with transaction cost theory, product and price determination is determined by the organization and its structure. Using blockchain, product and price decisions are made based on consensus among network users. In addition, in line with resource dependency theory, blockchain provides better control over resources and their consumption through information sharing and distributable systems. Managers can access transparent information of external sources by subscribing to blockchain networks.

Findings of the third hypothesis of the research showed that the use of blockchain technology and the degree of its adoption in the organization can have a positive effect on social sustainability. Blockchain-based system architecture has a positive effect on creating transparency and sustainability of the supply chain (Venkatesh et al., 2020). Due to the decentralization and distributability of the blockchain, a different structure of communication and data transfer is created in the organization that can affect people's interaction and organizational relationships. Also, the lack of concentration of power in the blockchain system can be effective in building democracy and increasing transparency, and the director of the organization and senior officials no longer deprive others of the right to comment and make decisions by accumulating information. In their study, Jaeger et al. (2021) found that poor inventory management, inefficient tracking, and non-standard products are major challenges in the green supply chain and sustainability. Therefore, blockchain can provide proper tracking and transparency in the green supply chain with the distributed system and immutability. Sustainable development is not possible without transparency and accountability (Asongu et al., 2018). Sustainable development does not require a top-down approach, but rather the creation of a network between people with a problem-solving attitude is effective (Sachs, 2012). Upadhyay et al. (2021) showed that the goals of sustainability and social responsibility and the prosperity of the circular economy can be achieved by sharing knowledge and participation in the blockchain-based network. In this regard, Agrawal et al. (2021) believe that digitalization can be a great help in the production of sustainable circular products. In addition, customer involvement is essential to creating sustainable circular products using digitization. The advantage of a circular business model is that organizations can reduce waste and operational delays through a sustainable solution (Upadhyay et al., 2019). Another effect of the blockchain is the reduction of fraud and information distortion due to encryption in the network (Bahga \& Madisetti, 2016). Such capabilities provide a suitable social environment for the interaction of employees and managers in the organization, which can improve the quality of work life of individuals. Reducing the information crime in the organization leads to social security, which is one of the factors of social sustainability. The fourth hypothesis of the research showed that business ethics has a positive effect on social sustainability. The results of the study by ElGammal et al. (2018) also showed that business ethics has an impact on social responsibility among companies operating in the Middle East. Business ethics is derived from the behavioral characteristics of people in the workplace and in relation to their jobs. Behavioral characteristics of individuals lead to the formation of social structure and social capital. Information exchange and knowledge sharing, interrelationships, norms and public trust all have a positive effect on social capital (Vikram, 2018). Chen and Cheung (2015) also argued that ethics affects corporate social 
responsibility. Therefore, appropriate and ethical individual behavior can be passed on to future generations as an asset in the organization. Behavior combined with honesty, trust and confidence is the basis for creating appropriate working relationships in the organization. An ethic-centered person does not think only of his own interests, so such thinking causes the way of using resources to be modified with regard to future generations. The last hypothesis of the study showed the positive effect of corporate governance on social sustainability. The results of the study by Mertzanis et al. (2018) also showed that among companies in the Middle East, corporate governance has a positive effect on corporate performance. The more appropriate the structure of labor and executive relations and the more facilitated executive processes by careful monitoring, the better the rights of stakeholders are secured. This appropriate structure can institutionalize a proper working mechanism in the organization that benefits the next generation of employees.

\subsection{Managerial implications}

The impact of using blockchain on business ethics shows that the managers of the organization should not look at blockchain technology only from the perspective of a technical and software tool, but this technology can affect organizational interactions and behavior of individuals. Upadhyay et al. (2020) cited knowledge sharing management as a blockchain opportunity, and Hughes (2017) noted the impact of blockchain on transparency and fraud prevention. In general, information asymmetries between the parties increase the likelihood of ethical problems, thus incurring more transactional costs for the organization because executives and stakeholders need more complex policies and agreements to deal with uncertainty and create transparency (Akerlof, 1970). Blockchain can cause proper distribution and symmetry of information in the network. Using the blockchain technology, organizations can improve the ethical standards of the organization and establish proper business interactions in the organization. Upadhyay et al. (2021) believe that blockchain technology, as a powerful tool for secure communication between participants, has the ability to facilitate the cleaner production of goods and services and address the ethical agenda of business development. Given that the companies under study are operating in the Middle East, the rank of the control of corruption index is one of the indicators of good governance in Iraq (7.21), Iran (15.87), and Turkey (43.75) (World Bank, 2019). Therefore, using the blockchain is a good solution to control immorality, such as corruption and information distortion and fraud in the organization.

Considering the positive impact of the blockchain on social sustainability, it can be concluded that if managers of organizations have a strategic and long-term perspective to maintain the survival of the organization, they can use this technology to create a platform for appropriate behavioral and social interactions in the organization. In this regard, findings of Upadhyay et al. (2021) study showed that the implementation of blockchain can help ensure human rights protection, increase the confidentiality of patient information and reduce carbon footprint. Given that the blockchain technology is an objective artifact, it can be passed on to future generations of the organization in the same way, and this method of behavioral interaction and information exchange in the organization is not eliminated with the departure or relocation of people. Kim (2017) found that the cost of bitcoin transactions is on average $2 \%$ lower than traditional transactions, so the use of blockchain technology is also economically justified. Therefore, organizations that are concerned with sustainability and have long-term attitude toward the interests of future generations can invest in the blockchain technology and its proper deployment in the organization. To enjoy the benefits 
of long-term sustainability, it is necessary to invest in blockchain and set up smart contracts, so investing in blockchain expertise and platform should be on the agenda of organizations (Iansiti \& Lakhani, 2017). Also, Upadhyay (2020) believes that "there is no guarantee that all the investment in sustainable practices will bring cost savings and ultimately generate profit" (Upadhyay, 2019, p.2). Given the environmental concerns in the Middle East and water scarcity in countries, such as Iran and Iraq, it can be suggested that the use of the blockchain technology can be a way to achieve sustainability. This is because the exchange of appropriate information in the organization and prevention of corruption and information distortion is a good solution to promote the correct pattern of using organizational and environmental resources. Luther (2016) believes that weak laws and lack of government support are one of the obstacles to the success of the blockchain technology and cryptocurrencies. The results of Upadhyay et al. (2020) study also showed that government regulatory is one of the challenges of using blockchain. The ICT Development Index of Turkey was 6.08 and that of Iran was 5.58 (ITU, 2017). Therefore, there is a need for more attention of executive bodies and policy makers to improve the situation of information technology in these countries. Accordingly, government institutions in Iran, Iraq and Turkey must provide the legal and technological basis for the implementation of the blockchain in business. Blockchain technology offers a variety of solutions for corporate governance. This technology can eliminate the intermediary factors in corporate governance through peer-to-peer connectivity, crowds, and collaboration. Blockchain-based guarantees ensure that no node in business transactions can violate governance rules (Kaal, 2021). That is, the board of directors of organizations need to use digital technologies to clarify the work processes of the organization and monitor the performance of executive agents in order to protect the interests of stakeholders. The use of blockchain and smart contracts is the beginning of fundamental changes in processing, recording, resolution, audit and reporting of transactions (Schmitz \& Leoni, 2019). Blockchain can improve operational security in the organization (Mani \& Chouk, 2018). Blockchain capabilities increase accuracy, costeffectiveness, and decentralization in the organization (Abadi \& Brunnermeier, 2018), so implementing blockchain can be a good way to achieve good corporate governance.

Business ethics among the surveyed companies had a positive effect on social sustainability, so the more SME managers can create a good ethical culture in the organization, the more they can expect constructive interaction of employees in order to conserve resources. Arab youth in the Middle East are more individualistic than their predecessors and are more relativistic and less idealistic, so they tend to engage in illegal ethical behavior (AlKhatib et al., 2002). Here, the role of leaders is very important to motivate ethical behavior and their power of influence among employees should be used. In this regard, Dickson et al. (2001) showed organizational leader has a considerable influence on their own personal values and their ethical behaviors. Holding training courses and creating a moral culture in the organization has an important role in promoting ethical behavior in the organization. Creating a sense of trust between people and increasing job satisfaction can be based on ethical behavior in the organization. Institutionalizing the golden rule of ethics, that is, treating others as you want to be treated, leads to better partnerships and constructive interaction between employees, resulting in social sustainability. Creating good corporate governance leads to social sustainability. The more the board of directors of organizations can create a better monitoring mechanism on the performance of executives, the more they can provide a suitable working environment for employees to interact and learn and be trained, which leads to social sustainability. Therefore, transparency of information, timely disclosure of financial statements, and constructive interaction between managers and employees determine the appropriate context for social sustainability in the organization. 


\section{Limitations and future research}

Sustainability consists of three main sub-categories including economic, environmental and social dimensions (Purvis et al., 2019). Rai et al. (2020) also presented the sustainability-resilience framework, in which they referred to two dimensions of sustainability, namely economic aspects and social aspects. Upadhyay et al. (2020) identified blockchain technology challenges, including open network design, security and privacy, resource wastage, energy consumption, lack of interoperability and scalability. Due to the fact that the social dimension of sustainability was examined in this study, the environmental effects and consumption of natural resources in the implementation of blockchain were not fully evaluated and are considered as a research limitation. Future research is suggested to consider the effect of blockchain on other dimensions of sustainability. This research was conducted in the Middle East region, which is mainly developing countries, so future studies are recommended to test the research model in developed countries and compare it with the results of this research. Another limitation of the research was model testing among SMEs, so the relationship between model variables can be tested in large businesses or across different industries and the results can be compared. In the model of this research, only four main constructs have been used. Future research is suggested to test constructs, such as social capital or corporate social responsibility, as a mediating variable in the model. One of the other limitations of this research was the use of accurate statistical calculations in estimating variables. Due to the use of uncertain values, such as fuzzy or gray approaches, it is suggested to evaluate the model variables with uncertain approaches in order to achieve more realistic values. Considering the following questions can help future research in the field of blockchain:

- How can blockchain affect sustainable development?

- Which blockchain architecture is more compatible with sustainability?

- Given the impact of blockchain on social sustainability, does blockchain lead to good governance?

\section{Conclusion}

Sustainable development is derived from social sustainability, and the basis for achieving sustainability is paying attention to social issues in the organization. The blockchain technology in the organization is not just a platform for digital currency, it rather creates a decentralized system to set the ground for transparent interaction and communication in the organization and uses information encryption capabilities to reduce information distortion and forgery. Blockchain technology is effective in business ethics, monitoring the behavior of executives and corporate governance, and ultimately achieving constructive social interactions and social sustainability. By implementing this technology, in addition to capabilities such as smart contracts, company managers can pave the way for achieving good corporate governance, promoting business ethics and achieving sustainability. Given the importance of natural resources, such as oil and water, for sustainable development and social sustainability in the Middle East, there is a need to make optimal use of new digital technologies, such as the blockchain. Therefore, business and IT policy makers of each country in the region need appropriate investment in IT and related technologies to conserve resources for future generations. 


\section{Appendix}

\section{The research questionnaire}

\begin{tabular}{|c|c|c|c|c|c|c|c|}
\hline Code & No. & Q. & \multicolumn{5}{|c|}{ Scale } \\
\hline \multirow{5}{*}{ DI } & 1 & Please select your country & \multicolumn{2}{|c|}{ Turkey } & Iraq & \multicolumn{2}{|c|}{ Iran } \\
\hline & 2 & Please specify your company size & \multicolumn{3}{|c|}{ Small enterprise } & \multicolumn{2}{|c|}{ Medium enterprise } \\
\hline & 3 & Please specify your size of board of directors & \multicolumn{3}{|c|}{$1-4$} & \multicolumn{2}{|c|}{$5-10$} \\
\hline & \multirow[t]{2}{*}{4} & \multirow[t]{2}{*}{ Please specify your work experience. } & $\begin{array}{l}\text { Below } \\
10 \text { Yrs }\end{array}$ & $\begin{array}{c}10-15 \\
\text { Yrs }\end{array}$ & \multicolumn{2}{|c|}{$15-20$ Yrs } & $\begin{array}{l}\text { Above } \\
20 \text { Yrs }\end{array}$ \\
\hline & & & 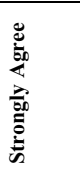 & 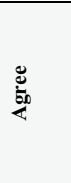 & 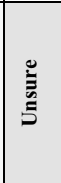 & 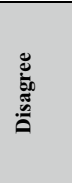 & 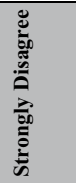 \\
\hline \multirow[t]{5}{*}{ WC } & 5 & $\begin{array}{l}\text { Convenience and accessibility are important in } \\
\text { the workplace }\end{array}$ & & & & & \\
\hline & 6 & $\begin{array}{l}\text { The number of annual and sick leave is } \\
\text { important in the organization }\end{array}$ & & & & & \\
\hline & 7 & $\begin{array}{l}\text { Attention is paid to the welfare and satisfaction } \\
\text { of employees in the organization }\end{array}$ & & & & & \\
\hline & 8 & $\begin{array}{l}\text { Job security and performance improvement are } \\
\text { important in the organization }\end{array}$ & & & & & \\
\hline & 9 & $\begin{array}{l}\text { Proper reward for performance is important to } \\
\text { the organization }\end{array}$ & & & & & \\
\hline \multirow{4}{*}{ WE } & 10 & $\begin{array}{l}\text { Amenities such as proper lighting and } \\
\text { ventilation are important for ease of operation }\end{array}$ & & & & & \\
\hline & 11 & $\begin{array}{l}\text { The amount of waste production is important } \\
\text { in the organization }\end{array}$ & & & & & \\
\hline & 12 & Noise pollution is important in the workplace & & & & & \\
\hline & 13 & $\begin{array}{l}\text { The rate of production of environmental } \\
\text { pollutants and the use of harmful substances } \\
\text { are important }\end{array}$ & & & & & \\
\hline \multirow{3}{*}{ WS } & 14 & $\begin{array}{l}\text { Exposure to chemical and toxic gases during } \\
\text { the production process is important }\end{array}$ & & & & & \\
\hline & 15 & $\begin{array}{l}\text { The level of industrial protection and work } \\
\text { safety is important in the organization }\end{array}$ & & & & & \\
\hline & 16 & $\begin{array}{l}\text { Control of occupational accidents during } \\
\text { production operations is important in the } \\
\text { organization }\end{array}$ & & & & & \\
\hline \multirow{2}{*}{ SD } & 17 & $\begin{array}{l}\text { On-the-job training and improving staff skills } \\
\text { are important }\end{array}$ & & & & & \\
\hline & 18 & $\begin{array}{l}\text { There is employee participation in decision- } \\
\text { making processes in the organization }\end{array}$ & & & & & \\
\hline \multirow{9}{*}{ os } & 19 & $\begin{array}{l}\text { Existing laws control the performance of the } \\
\text { company and the executive agents }\end{array}$ & & & & & \\
\hline & 20 & $\begin{array}{l}\text { Shareholders are made up of a variety of } \\
\text { people }\end{array}$ & & & & & \\
\hline & 21 & Annual meetings are held regularly & & & & & \\
\hline & 22 & $\begin{array}{l}\text { The rules are to monitor the decisions of } \\
\text { managers }\end{array}$ & & & & & \\
\hline & 23 & $\begin{array}{l}\text { There is monitoring of the value of the } \\
\text { company's stock }\end{array}$ & & & & & \\
\hline & 24 & $\begin{array}{l}\text { The governance structure is to protect the } \\
\text { rights of stakeholders and shareholders }\end{array}$ & & & & & \\
\hline & 25 & $\begin{array}{l}\text { The mission and vision of the company are } \\
\text { approved and specified }\end{array}$ & & & & & \\
\hline & 26 & $\begin{array}{l}\text { The criteria for selecting board members are } \\
\text { clear and structured }\end{array}$ & & & & & \\
\hline & 27 & $\begin{array}{l}\text { The rules for breaking the law and causing } \\
\text { harm to the rights of stakeholders are clear }\end{array}$ & & & & & \\
\hline \multirow{6}{*}{$\mathrm{AC}$} & 28 & Audit costs are known & & & & & \\
\hline & 29 & The period of the auditors' contract is clear & & & & & \\
\hline & 30 & The internal control system is clear and precise & & & & & \\
\hline & 31 & $\begin{array}{l}\text { There is a process of rotation and relocation of } \\
\text { auditors }\end{array}$ & & & & & \\
\hline & 32 & $\begin{array}{l}\text { The amount of auditors' remuneration and their } \\
\text { participation is transparent }\end{array}$ & & & & & \\
\hline & 33 & $\begin{array}{l}\text { The process of selecting external auditors is } \\
\text { clear }\end{array}$ & & & & & \\
\hline
\end{tabular}




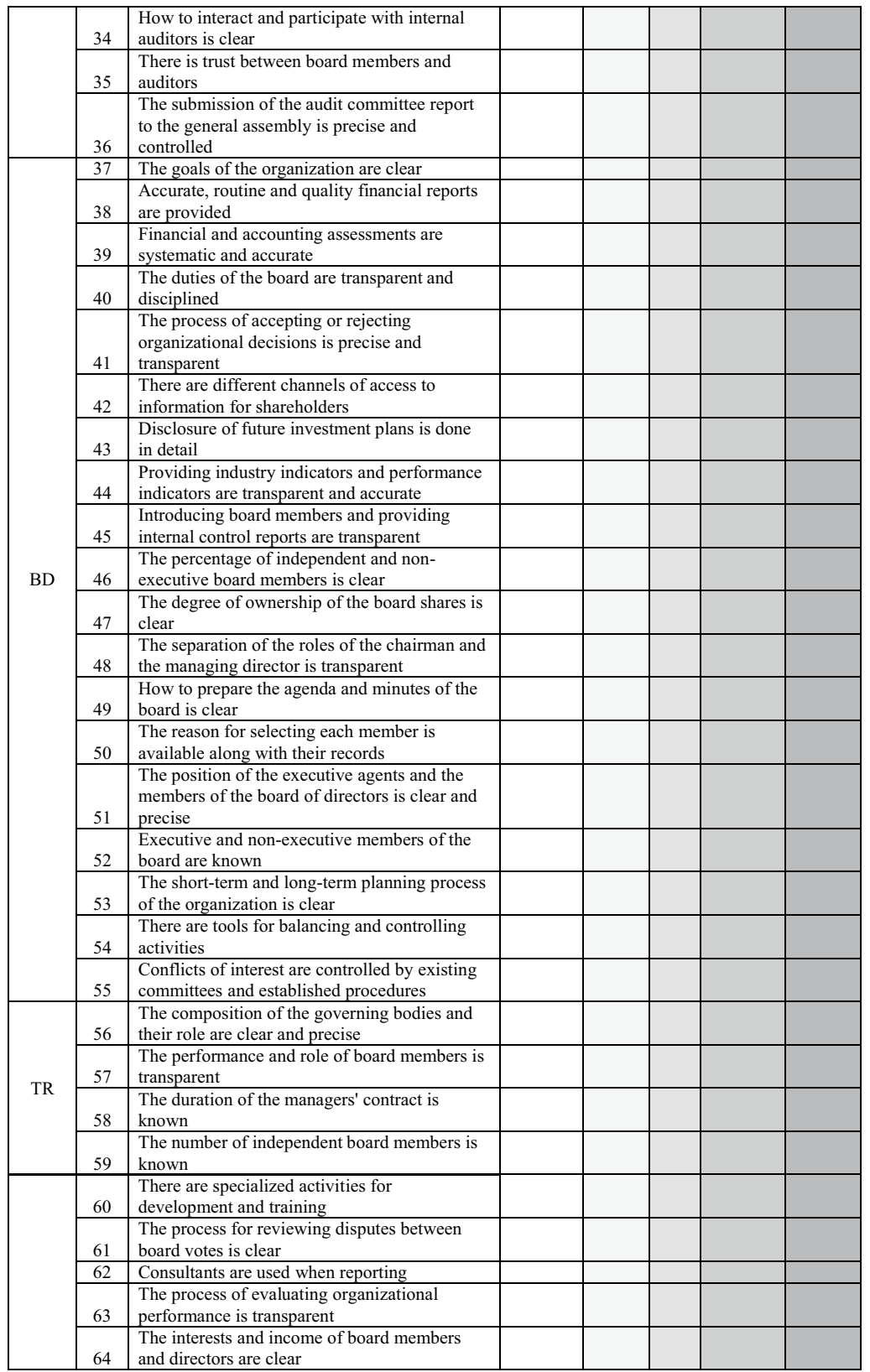




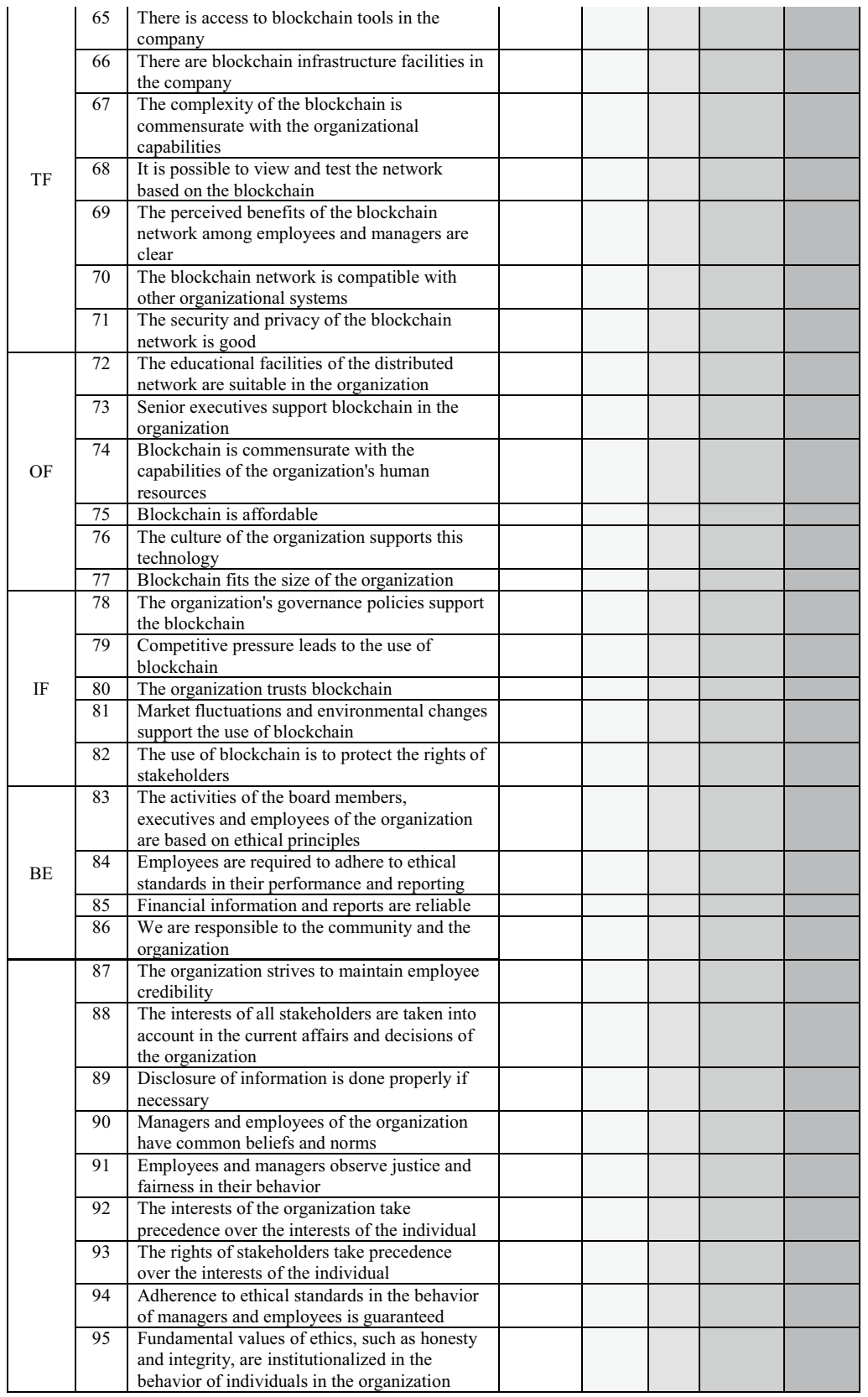


Funding The author(s) received no financial support for the research, authorship, and/or publication of this article.

Availability of data and material All data generated or analyzed during this study are included in this article.

\section{Declarations}

Conflicts of interests The author(s) declared no potential conflicts of interest with respect to the research, authorship, and/or publication of this article.

Ethical approval The author(s) declare that there are no ethical conflicts associated with the submitted manuscript.

\section{References}

Abadi, J. and Brunnermeier M. (2018). Blockchain Economics (No. w25407). National Bureau of Economic Research. Available online: https://www.nber.org/papers/w25407 (accessed on 1 June 2020).

Agrawal, R., Wankhede, V. A., Kumar, A., Upadhyay, A., \& Garza-Reyes, J. A. (2021). Nexus of circular economy and sustainable business performance in the era of digitalization. International Journal of Productivity and Performance Management. https://doi.org/10.1108/IJPPM-12-2020-0676

R Aguilera, V Ruth, Alvaro Cuervo-Cazurra. 2009. Codes of Good Governance Corporate Governance An International Review. 17376 87. https://doi.org/10.1111/j.1467-8683.2009.00737.x

Ahlering B. and Deakin S. (2007). Labor Regulation, Corporate Governance and Legal Origin: A Case of Institutional Complementarity? Law \& Society Review 41, 865-908. www.jstor.org/stable/4623417

Ajmal, M. M., Khan, M., Hussain, M., \& Helo, P. (2017). Conceptualizing and incorporating social sustainability in the business world. International Journal of Sustainable Development \& World Ecology, 25(4), 327-339. https://doi.org/10.1080/13504509.2017.1408714

Akerlof, G. A. (1970). The market for 'lemons': Quality uncertainty and the market mechanism. Quarterly Journal of Economics, 84(3), 488-500.

Akgiray, V. (2019). The potential for blockchain technology in corporate governance. In OECD Corporate Governance Working Papers No. 21. https://doi.org/10.1787/ef4eba4c-en.

Al-Khatib, J. A., Robertson, C. J., D’Auria, S. A., \& Vitell, S. J. (2002). Business ethics in the Arab Gulf States: a three-country study. International Business Review, 11(1), 97-111. https://doi.org/10.1016/ S0969-5931(01)00049-X

Asif, M., Jajja, M. S. S., and Searcy, C. (2019). Social compliance standards: Re-evaluating the buyer and supplier perspectives. Journal of Cleaner Production. 227, 457-471. https://doi.org/10.1016/j.jclepro. 2019.04.157

Asongu, S. A., Le Roux, S., \& Biekpe, N. (2018). Enhancing ICT for environmental sustainability in subSaharan Africa. 665. Technological Forecasting and Social Change., 127, 209-216. https://doi.org/ 10.1016/j.techfore.2017.09.022

Bahga, A., \& Madisetti, V. K. (2016). Blockchain platform for industrial internet of things. Journal of Software Engineering and Applications, 9(10), 533-546. https://doi.org/10.4236/jsea.2016.910036

Bansal, P. (2005). Evolving sustainably: A longitudinal study of corporate sustainable development. Strategic Management Journal, 26(3), 197-218. https://doi.org/10.1002/smj.441

Baraua, A. S., Stringer, L. C., \& Adamu, A. U. (2016). Environmental ethics and future oriented transformation to sustainability in Sub-Saharan Africa. Journal of Cleaner Production, 135, 1539-1547. https:// doi.org/10.1016/j.jclepro.2016.03.053

Brav, A., \& Mathews, R. D. (2011). Empty Voting and the Efficiency of Corporate Governance. Journal of Financial Economics, 99, 289-307. https://doi.org/10.1016/j.jfineco.2010.10.005

Carter, C. R., \& Easton, P. L. (2011). Sustainable supply chain management: evolution and future directions. International Journal of Physical Distribution \& Logistics Managemen., 41(1), 46-62. https://doi. org/10.1108/09600031111101420

Carter, C. R., \& Rogers, D. S. (2008). A framework of sustainable supply chain management: moving toward new theory. Int. J. Phys. Distrib. Logist. Manage., 38(5), 360-387. https://doi.org/10.1108/ 09600030810882816 
Castelo-Branco, I., Cruz-Jesus, F., \& Oliveira, T. (2019). Assessing Industry 4.0 readiness in manufacturing: Evidence for the European. Union Computers in Industry, 107, 22-32. https://doi.org/10.1016/j. compind.2019.01.007

Catalini, C., and Gans J. S., (2016). Some Simple Economics of the Blockchain (No. w22952). Cambridge: National Bureau of Economic Research. www.nber.org/papers/w22952.pdf

Catalini, C. and Tucker, C.E. (2018). Antitrust and costless verification: an optimistic and a pessimistic view of the implications of blockchain technology, MIT Sloan Research Paper No. 5523-18, June19, https://doi.org/10.2139/ssrn.3199453;https://papers.ssrn.com/sol3/papers.cfm?abstract_id=3199453

Cheffins, B. R. (2013). The history of corporate governance. In M. Wright, \& et al. (Eds.). The Oxford handbook of corporate governance. Oxford University Press.

Chen A.K. and Chaung S.Y.L. (2015). Special Issue on Corporate Social Responsibility and Sustainability An Introduction. Journal of Business Ethics. 130 753-754. https://doi.org/10.1007/ s10551-015-2849-0

Claessens, S., \& Yurtoglu, B. B. (2013). Corporate governance in emerging markets: a survey. Emerging Markets Review, 15(1), 1-33. https://doi.org/10.1016/j.ememar.2012.03.002

Clark, W. C. (2007). Sustainability science: a room of its own. Proceedings of the National Academy of Sciences, 104(6), 1737-1738.

Darcy, C., Hill, J., McCabe, T., \& McGovern, P. (2014). A consideration of organizational sustainability in the SME context: A resource-based view and composite model. European Journal of Training and Development, 38(5), 398-414. https://doi.org/10.1108/EJTD-10-2013-0108

Davidson, S., De Filippi, P., \& Potts, J. (2018). Blockchains and the economic institutions of capitalism. Journal of Institutional Economics, 14(4), 639-658. https://doi.org/10.1017/S1744137417000200

De Filippi, P., Mannan, M., \& Reijers, W. (2020). Blockchain as a confidence machine: The problem of trust \& challenges of governance. Technology in Society, 62, 101284. https://doi.org/10.1016/j.techs oc. 2020.101284

Dickson, M. W., Smith, D. B., Grojean, M. W., \& Ehrhart, M. (2001). An organizational climate regarding ethics: the outcome of leader values and the practice that reflect them. The Leadership Quarterly, 12, 197-217.

Digalwar, A.K., Dambhare, S. and Saraswat, S. (2019). Social sustainability assessment framework for indian manufacturing industry, Materials Today: Proceedings, https://doi.org/10.1016/j.matpr.2019. 12.226

ElGammal, W., El-Kassar, A., \& Messarra, L. C. (2018). Corporate ethics, governance and social responsibility in MENA countries. Management Decision, 56(1), 273-291. https://doi.org/10.1108/ MD-03-2017-0287

Esmaeilian B., Sarkis, J., Lewis, K. and Behdad, S. (2020). Blockchain for the future of sustainable supply chain management in Industry 4.0. Resources, Conservation and Recycling. 163 105064. https://doi. org/10.1016/j.resconrec.2020.105064

Esposito Vinzi, V., Chin, W. W., Henseler, J., \& Wang, H. (2010). Handbook of partial least squares: Concepts, methods and applications. Springer Verlag.

Farouk, A., Alahmadi, A., Ghose, S., \& Mashatan, A. (2020). Blockchain platform for industrial healthcare: Vision and future opportunities. Computer Communications., 154, 223-35. https://doi.org/10.1016/j. comcom.2020.02.058

Ferrell, O. C., Harrison, D. E., Ferrell, L., \& Hari, J. F. (2019). Business ethics, corporate social responsibility, and brand attitudes: An exploratory study. Journal of Business Research, 95, 491-501. https://doi. org/10.1016/j.jbusres.2018.07.039

Filippi, P.D. and Loveluck, B. (2016), The invisible politics of bitcoin governance crisis of a decentralized infrastructure. Internet Policy Review. 5 (4) 1-32. https://doi.org/10.14763/2016.3.427

Fischer, D. (2018), Ethical and professional implications of blockchain accounting ledgers, November 30, available at: https://ssrn.com/abstract=3331009. https://doi.org/10.2139/ssrn.3331009

Fornell, C., \& Larcker, D. F. (1981). Structural equation models with unobservable variables and measurement error: algebra and statistics. Journal of Marketing Research, 18(3), 382-388. https://doi.org/10. $2307 / 3150980$

Frizzo-Barker, J., Chow-White, P. A., Adams, P. R., Mentanko, J., Ha, D., \& Green, Sandy. (2020). Blockchain as a disruptive technology for business: a systematic review. International Journal of Information Management, 51, 102-029. https://doi.org/10.1016/j.ijinfomgt.2019.10.014

Gelhard, C., \& von Delft, S. (2016). The role of organizational capabilities in achieving superior sustainability performance. Journal of Business Research, 69(10), 4632-4642. https://doi.org/10.1016/j.jbusres. 2016.03.053

Goel, A. (2015). Blockchain use cases: Comprehensive analysis \& startups involved. Medici. Retrieved from www.gomedici.com/blockchain-use-cases-comprehensive-analysis-startups-invoved/ 
Grover, V., \& Kohli, R. (2013). revealing your hand: caveats in implementing digital business strategy. MIS Quarterly, 37, 655-663.

Gupta, S., \& Sadoghi, M. (2018). Blockchain transaction processing. Encyclopedia of Big Data Technologies Springer International Publishing. https://doi.org/10.1007/978-3-319-63962-8_333-1

Hahn, T., \& Figge, F. (2018). Why architecture does not matter: on the fallacy of sustainability balanced scorecards. Journal of Business Ethics, 150(4), 919-935. https://doi.org/10.1007/s10551-016-3135-5

Hair, Jr. J.F., Hult, G.T.M., Ringle, C. and Sarstedt, M., (2016). A primer on partial least squares structural equation modeling (PLS-SEM), Sage Publications

Hang, L., \& Kim, D. H. (2021). Optimal Blockchain Network Construction Methodology Based on Analysis of Configurable Components for Enhancing Hyperledger Fabric Performance. Blockchain: Research and Applications. https://doi.org/10.1016/j.bcra.2021.100009

Haq, S., \& Boz, I. (2019). Measuring environmental, economic, and social sustainability index of tea farms in Rize Province. Turkey, Environment, Development and Sustainability. https://doi.org/10.1007/ s10668-019-00310-X

Harding, G. (1968). The tragedy of the commons. Science, 162, 1245-1248.

Helo, P., \& Hao, Y. (2019). Blockchains in operations and supply chains: a model and reference implementation. Computers \& Industrial Engineering, 136, 242-251. https://doi.org/10.1016/j.cie.2019.07.023

Herian, R. (2018). The politics of blockchain. Law and Critique, 29(2), 129-131.

Hillman, A. J., Cannella, A. A., \& Paetzold, R. L. (2000). The Resource dependence role of corporate directors: strategic adaptation of board composition in response to environmental change. Journal of Management Studies, 37(2), 235-256. https://doi.org/10.1111/1467-6486.00179

Hofmann, E., \& Rüsch, M. (2017). Industry 4.0 and the current status as well as future prospects on logistics. Computers in Industry, 89, 23-34. https://doi.org/10.1016/j.compind.2017.04.002

Hu, Y., Hou, Y., Oxley, L., \& Corbet, S. (2021). Does blockchain patent-development influence Bitcoin risk? Journal of International Financial, Markets. Institutions \& Money, 70, 101263. https://doi.org/ 10.1016/j.intfin.2020.101263

Hughes, K. (2017). Blockchain, the greater good, and human and civil rights. Meta Philosophy, 48(5), 654-665.

Hult, G. T. M. (2011). Market-focused sustainability: Market orientation plus! Journal of the Academy of Marketing Science, 39(1), 1-6. https://doi.org/10.1007/s11747-010-0223-4

Iansiti, M., Lakhani, K.R., (2017). The truth about blockchain. Harvard Business Review. 119e127

ITU, (2017). ICT Development index, https://www.itu.int/net4/ITU-D/idi/2017/index.html

Izraeli, D. (1997). Business Ethics in the Middle East. Journal of Business Ethics, 16, 1555-1560.

Jaeger, B., Menebo, M.M. and Upadhyay, A. (2021). Identification of environmental supply chain bottlenecks: A case study of the Ethiopian Healthcare Supply Chain. Management of Environmental Quality: An International Journal, https://doi.org/10.1108/MEQ-12-2019-0277

Kaal, W.A. (2021). Blockchain-Based Corporate Governance, Stanford Journal of Blockchain Law \& Policy Retrieved from https://stanford-jblp.pubpub.org/pub/blockchain-corporate-governance

Kewell, B., Adams, R., \& Parry, G. (2017). Blockchain for good? Strategic Change., 26(5), 429-437. https://doi.org/10.1002/jsc. 2143

Kim, T. (2017). On the transaction cost of bitcoin. Finance Research Letters, 23, 300-305. https://doi.org/ 10.1016/j.frl.2017.07.014

Kouhizadeh, M., Saberi, S., \& Sarkis, J. (2020). Blockchain technology and the sustainable supply chain: Theoretically exploring adoption barriers. International Journal of Production Economics. https:// doi.org/10.1016/j.ijpe.2020.107831

Krechovská, M., \& Prochazkova, P. T. (2014). Sustainability and its integration into corporate governance focusing on corporate performance management and reporting, 24th DAAAM international symposium on intelligent manufacturing and automation. Procedia Engineering., 69, 1144-1151. https:// doi.org/10.1016/j.proeng.2014.03.103

Krishna, A., Dangayach, G. S., \& Jain, R. (2011). Business ethics: a sustainability approach, international conference on asia pacific business innovation \& technology management. Procedia - Social and Behavioral Sciences, 25(2011), 281-286. https://doi.org/10.1016/j.sbspro.2011.10.548

Kumar, N., Brint, A., Shi, E., Upadhyay, A., \& Ruan, X. (2019). Integrating sustainable supply chain practices with operational performance: an exploratory study of Chinese SMEs. Production Planning \& Control, 30(5-6), 464-478. https://doi.org/10.1080/09537287.2018.1501816

Lafarre, A. and van der Elst C. (2018). Blockchain Technology for Corporate Governance and Shareholder Activism, ECGI Law Working Paper (390/2018)

Lashley, C. (2016). Business ethics and sustainability. Research in Hospitality Management, 6(1), 1-7. https://doi.org/10.2989/RHM.2016.6.1.1.1289 
Lee, C. M. J., Che-Ha, N., \& Alwi, S. A. S. (2019). Service customer orientation and social sustainability: the case of small medium enterprises. Journal of Business Research. https://doi.org/10.1016/j.jbusres. 2019.12.048

Leng, J., Ruan, G., Jiang, P., Xu, K., Liu, Q., Zhou, X., \& Liu, C. (2020). Blockchain-empowered sustainable manufacturing and product lifecycle management in industry 40 a survey. Renewable and Sustainable Energy Reviews, 132, 110112. https://doi.org/10.1016/j.rser.2020.110112

Li, Z., Crook, J., Andreeva, G., \& Tang, Y. (2020). Predicting the risk of financial distress using corporate governance measures. Pacific-Basin Finance Journal. https://doi.org/10.1016/j.pacfin.2020.101334

Liu, S., Leat, M., \& Smith, M. H. (2011). State-of-the-art sustainability analysis methodologies for efficient decision support in green production operations. International Journal of Sustainable Engineering, 4(3), 236-250. https://doi.org/10.1080/19397038.2011.574744

Lu, M.-T., Tsai, J.-F., Shen, S.-P., Lin, M.-H., \& Hu, Y.-C. (2020). Estimating sustainable development performance in the electrical wire and cable industry: applying the integrated fuzzy MADM approach. Journal of Cleaner Production. https://doi.org/10.1016/j.jclepro.2020.122440

Luther, W. J. (2016). Cryptocurrencies, network E_ects, and switching costs. Contemporary Economic Policy, 34, 553-571. https://doi.org/10.1111/coep.12151

Mani, V., Gunasekaran, A., Papadopoulos, T., Dubey, R., \& Benjamin, H. (2016). Supply chain social sustainability for developing nations: evidence from India. Resources, Conservation \& Recycling., 111, 42-52. https://doi.org/10.1016/j.resconrec.2016.04.003

Mani, V., Jabbour, C. J., \& Mani, K. (2020). Supply chain social sustainability in small and medium manufacturing enterprises and firms' performance: Empirical evidence from an emerging Asian economy. International Journal of Production Economics, 227, 107656. https://doi.org/10.1016/j.ijpe.2020. 107656

Mani, Z., \& Chouk, I. (2018). Consumer Resistance to Innovation in Services: Challenges and Barriers in the Internet of Things Era. Journal of Product Innovation Management, 35(5), 780-807.

Mertzanis, C., Basouny, M., \& Mohamed, E. K. (2018). Social institutions corporate governance firm-performance in the MENA region. Research in International Business and Finance. https://doi.org/10. 1016/j.ribaf.2018.12.005

Naciti, V. (2019). Corporate governance and board of directors: The effect of a board composition on firm sustainability performance. Journal of Cleaner Production, 237, 117727. https://doi.org/10.1016/j. jclepro.2019.117727

Narayanan, A., \& Clark, J. (2017). Bitcoin's academic pedigree. Communications of the ACM, 60(12), 36-45. https://doi.org/10.1145/3132259

Nikolakis, W., John, L., \& Krishnan, H. (2018). Sustainability, 10(11), 3926. https://doi.org/10.3390/su101 13926

OPEC, (2019). OPEC annual statistical bulletin, https://www.opec.org/opec_web/en/data_graphs/330.htm

Orji, I. J., Kusi-Sarpong, S., Huang, S., \& Vazquez-Brust, D. (2020). Evaluating the factors that influence blockchain adoption in the freight logistics industry. Transportation Research Part E, 141, 102025. https://doi.org/10.1016/j.tre.2020.102025

Paille, P., Amara, N., \& Halilem, N. (2018). Greening the workplace through social sustainability among coworkers. Journal of Business Research, 89(8), 305-312. https://doi.org/10.1016/j.jbusres.2017.12.044

Peng, L., Feng, W., Yan, Z., Li, Y., Zhou, X., \& Shimizu, S. (2020). Privacy preservation in permissionless blockchain: a survey. Digital Communications and Networks. https://doi.org/10.1016/j.dcan. 2020.05 .008

Pfeffer, J. (2010). Building sustainable organizations: the human factor. Academy of Management Perspectives. https://doi.org/10.2139/ssrn.1545977

Piazza, F. S. (2017). Bitcoin and the Blockchain as Possible Corporate Governance Tools: Strengths and Weaknesses. Penn State. Journal of Law \& International Aairs, 5, 262-301.

Purvis, B., Mao, Y., Robinson, D., (2019). Three pillars of sustainability: in search of conceptual origins. Sustainability Science. 14 (3) 681e695. https://doi.org/10.1007/s11625-018-0627-5

Rahimzadeh, V. (2018), Ethics governance outside the box: reimagining blockchain as a policy tool to facilitate single ethics review and data sharing for the 'omics' sciences, Blockchain in Healthcare Today, 1, 1-10. https://doi.org/10.30953/bhty.v1.18

Rai, S. S., Rai, S., \& Singh, N. K. (2021). Organizational resilience and social-economic sustainability: COVID-19 perspective. Environment, Development and Sustainability. https://doi.org/10.1007/ s10668-020-01154-6

Raval, S. (2016). Decentralized applications: Harnessing Bitcoin's Blockchain Technology (p. 2016). O’Reilly Media Inc.

Risius, M., \& Spohrer, K. (2017). A blockchain research framework. Business \& Information Systems Engineering, 59(6), 385-409. https://doi.org/10.1007/s12599-017-0506-0 
Ronaghi, M. H. (2020). A blockchain maturity model in agricultural supply chain. Information Processing in Agriculture. https://doi.org/10.1016/j.inpa.2020.10.004

Ronaghi, M. H., \& Forouharfar, A. (2020). A contextualized study of the usage of the Internet of things (IoTs) in smart farming in a typical Middle Eastern country within the context of unified theory of acceptance and use of technology model (UTAUT). Technology in Society, 63, 101415. https://doi. org/10.1016/j.techsoc.2020.101415

Saberi, S., Kouhizadeh, M., Sarkis, J., \& Shen, L. (2018). Blockchain technology and its relationships to sustainable supply chain management. International Journal of Production Research, 57(7), 2117-2135. https://doi.org/10.1080/00207543.2018.1533261

Sachs, J.D., (2012). From millennium development goals to sustainable development goals. Lancet 379 , 2206e2211. https://doi.org/10.1016/S0140-6736(12)60685-0.

Sajko, M., Boone, C., \& Buyl, T. (2020). CEO greed, corporate social responsibility, and organizational resilience to systemic shocks. Journal of Management, 47(4), 957-992. https://doi.org/10.1177/ 0149206320902528

Salvioni, D. M., \& Gennari, F. (2014). Corporate governance, sustainability and capital markets orientation. International Journal of Management and Sustainability, 3(8), 469-483.

Saunders, M., Lewis, P. and Thornhill, A. (2012). Research Methods for Business Students, $6^{\text {th }}$ edition, Pearson Education Limited.

Schmitz, J. and Leoni, G., (2019). Accounting and auditing at the time of blockchain technology: a research agenda. Australian Accounting Review. 29 (2) 331e342. https://doi.org/10.1111/auar. 12286

Schrobback, P., \& Meath, C. (2020). Corporate sustainability governance: insight from the Australian and New Zealand port industry. Journal of Cleaner Production, 255, 120280. https://doi.org/10. 1016/j.jclepro.2020.120280

Schuetz, S. W., \& Venkatesh, V. (2019). Blockchain, adoption, and financial inclusion in India: Research opportunities. International journal of information management, 52, 101936. https://doi.org/10. 1016/j.ijinfomgt.2019.04.009

Schulte, U. G. (2013). New business models for a radical change in resource efficiency. Environmental Innovation and Societal. Transitions., 9, 43e47. https://doi.org/10.1016/j.eist.2013.09.006

Schulz, K. A., Gstrein, O. J., \& Zwitter, A. J. (2020). Exploring the governance and implementation of sustainable development initiatives through blockchain technology. Futures, 122, 102611. https:// doi.org/10.1016/j.futures.2020.102611

Siegfried, N., Rosenthal, T. and Benlian, A. (2020). Blockchain and the Industrial Internet of Things: A requirement taxonomy and systematic fit analysis, Journal of Enterprise Information Management, ahead-of-print(ahead-of-print), 1-23. https://doi.org/10.1108/JEIM-06-2018-0140

Stahl, B. C., Chatfield, K., Holter, C. T., \& Brem, A. (2019). Ethics in corporate research and development: can responsible research and innovation approaches aid sustainability? Journal of Cleaner Production, 239, 118044. https://doi.org/10.1016/j.jclepro.2019.118044

Tang, C. S. (2018). Socially responsible supply chains in emerging markets: some research opportunities. Journal of Operations Management, 57, 1-10.

Tang, Y., Xiong, J., Becerril-Arreola, R., \& Iyer, L. (2020). Ethics of blockchain: a framework of technology, applications, impacts, and research directions. Information Technology \& People, 33(2), 602632. https://doi.org/10.1108/ITP-10-2018-0491

Tapscott, D., \& Tapscott, A. (2017). How blockchain will change organizations. MIT Sloan Management Review, 58(2), 10-13.

Upadhyay, A. (2020). Antecedents of green supply chain practices in developing economies. Management of Environmental Quality An International Journal. https://doi.org/10.1108/MEQ-12-2019-0274

Upadhyay, A., Akter, S., Adams, L., Kumar, V., \& Varma, N. (2019). Investigating circular business models" in the manufacturing and service sectors. Journal of Manufacturing Technology Management. https://doi.org/10.1108/JMTM-02-2018-0063

Upadhyay, A., Ayodele, J., Kumar, A., \& Garza-Reyes, J. A. (2020). A review of challenges and opportunities of blockchain adoption for operational excellence in the UK automotive Industry. Journal of Global Operations and Strategic Sourcing. https://doi.org/10.1108/JGOSS-05-2020-0024

Upadhyay, A., Mukhuty, S., Kumar, V., \& Kazancoglu, Y. (2021). Blockchain technology and the circular economy: Implications for sustainability and social responsibility. Journal of Cleaner Production, 293, 126130. https://doi.org/10.1016/j.jclepro.2021.126130

Venkatesh, V. G., Kang, K., Wang, B., Zhong, R. Y., \& Zhang, A. (2020). System architecture for blockchain based transparency of supply chain social sustainability. Robotics and Computer Integrated Manufacturing, 63, 101896. https://doi.org/10.1016/j.rcim.2019.101896 
Vikram, K. (2018). Social capital and child nutrition in India: the moderating role of development. Health \& Place, 50, 42-51. https://doi.org/10.1016/j.healthplace.2017.12.007

Williamson, O. E. (1996). Economic organization: the case for candor. The Academy of Management Review, 21, 48-57. https://doi.org/10.5465/amr.1996.9602161564

World Bank (2019). Worldwide Governance Indicators, https://info.worldbank.org/governance/wgi/

Yazdanpanah, M., Feyzabad, F. R., Forouzani, M., Mohammadzadeh, S., \& Burton, R. (2015). Predicting farmers' water conservation goals and behavior in Iran: a test of social cognitive theory. Land Use Policy, 47, 401-407. https://doi.org/10.1016/j.landusepol.2015.04.022

Yermack, D. (2017). Corporate governance and blockchains. Review of Finance, 21(1), 7-31. https://doi. org/10.1093/rof/rfw074

Zachariadis, M., Hileman, G., \& Scott, S. V. (2019). Governance and control in distributed ledgers: understanding the challenges facing blockchain technology in financial services. Information and Organization, 29, 105-117.

Publisher's Note Springer Nature remains neutral with regard to jurisdictional claims in published maps and institutional affiliations. 